Terbit online pada laman web jurnal : http://e-journal.sastra-unes.com/index.php/JILP

\begin{tabular}{|c|c|c|}
\hline \multirow[b]{2}{*}{$\begin{array}{c}\text { Fakultas Sastra } \\
\text { Universitas Ekasakti } \\
\end{array}$} & \multicolumn{2}{|c|}{$\begin{array}{c}\text { (Jurnal Ilmiah Langue and Parole) } \\
\text { Volume } 4 \text { Nomor } 2\end{array}$} \\
\hline & $\begin{array}{c}\text { ISSN : 2581-0804 } \\
\text { (Media Cetak) }\end{array}$ & $\begin{array}{c}\text { E-ISSN : 2581-1819 } \\
\text { (Media Online) }\end{array}$ \\
\hline Received: 19-07-2021 & Revised: $25-07-2021$ & Available online:10-08-2021 \\
\hline
\end{tabular}

\title{
AN ANALYSIS OF CODE-MIXING FOUND ON DEDDY CORBUZIER'S YOUTUBE CHANNEL SELECTED PODCAST
}

\author{
Raflis, Mia Gusnita \\ Fakultas Sastra Universitas Ekasakti \\ raflisdrs@gmail.com, nyagusnita@gmail.com \\ *Corresponding Author: Mia Gusnita \\ Fakultas Sastra Universitas Ekasakti \\ nyagusnita@gmail.com
}

\begin{abstract}
Code-Mixing can occur in all circles of society or social status. Code-mixing found in a language, someone cannot prevent code-mixing. The speaker usually speaks two languages and speaker put words or phrase from other languages in the speech or it can be said that code-mixing can occur in direct or indirect situation. Code-Mixing is the change of one language or two languages into another language. Code-mixing can occur in spoken or written text. Therefore, the researcher wants to know the code mixing contained in selected podcast. This study uses Pieter Mueysken's theory of insertion, alternation, and congruent lexicalization. Researcher used qualitative methods. The purpose of this research is to divide the types and explain code mixing based on reasons and factors. After collecting all the data, the researcher found 257 utterances that contain of code-mixing. Code-mixing contained in the insertion there were 158 data 61, 5\%), 81 data of alternation (31, 5\%), 18 data of congruent lexicalization (7, 0\%). Talking about particular topic there were 3 data (1, $17 \%)$, empathy about something there were 4 data (1,55\%), repetition used clarificarion there were 12 data (4, 67\%). Message intrinsic factor 2 data (0, 77\%).
\end{abstract}

Keywords: Code-mixing, Deddy Corbuzier's Podcast.

(C) 2021Jurnal JILP

\section{INTRODUCTION}

When two or more people communicate with each other, we can call the system they use a code, (Wardhaugh and Fuller, 2015: 3). In communications, a code is a rule for converting a piece of information, for example, a letter, word, or phrase into another form or representation, not necessarily of the same sort. In communications, and information processing, encoding is the process by which a source object performs this conversation of information into data, (Liu, 2006: 3).

This study aims to better identify the mixing of languages used by Deddy Corbuzier. The listeners who can learn English in the form of words, phrases or sentences.

Jurnal JILP (Jurnal Ilmiah Langue and Parole) Vol. 4 No. 2 (2021) ISSN : 2581-0804

This work is licensed under a Creative Commons Attribution-NonCommercial 4.0 International License. 
The researcher interested with this research because it is as a recent phenomenon in the social media networking especially YouTube. Based on data quoted from Social Media in 2019, YouTube was the most used social media by Indonesian internet users. YouTube is the most active social media the percentage reaches 88\% above Facebook, Instagram, and other social media, (Helianthusonfri, 2020: 4).

Nowadays, code-mixing is becoming a language phenomenon. First, code- mixing can

\section{RESEARCH METHODS}

The researcher chooses the descriptive qualitative method because the researcher provided descriptive data in the form of written data through Deddy Corbuzier's podcast.

"Metodologi kualitatif merupakan prosedur yang menghasilkan data deskriptif berupa data tulisan ataupun lisan di masyarakat. Metode penelitian deskriptif cenderung digunakan dalam penelitian kualitatif, terutama dalam mengumpulkan data, serta menggambarkan data secara ilmiah. Metode kajian dapat digunakan beragam tergantung pada pendekatan

\section{RESULTS AND DISCUSSION}

According to (Liu, 2006: 4) code-mixing hypothesis states that when two code switched languages constitute the appearance of a third code it has structural characteristic special to the new code. Code-mixing is the change of one language or two languages to another within the same utterance or in the same oral or written text

\subsection{Types of Code-Mixing}

According to (Muysken, 2000: 3). Theory of code-mixing are divided into three types. There are three types of code-mixing such as Insertion, Alternation, and Congruent lexicalization. be applied in social interactions in bilingual community communication. Second, many people including artists also use code- mixing. Today, many people mix languages in speaking it is something that usually happens because of following trends to be accepted in social groups. Humans have the abilities to accept more than one language one of the factors is the environment. teori yang akan digunakan

untuk mendiskripsikan data

secara akurat, serta

menghasilkan kaidah-kaidah

kebahasaan secara lingustik"

(Djajasudarma, 2006: 9).

Qualitative methodology is a procedure that produces descriptive qualitative in the form of written or oral data in the community. Descriptive research methods tend to be used in qualitative research, especially in collecting data and describing data scientifically. Various study methods can be used depending on the theoretical approach that will be used to describe data accurately and produce linguistic rules linguistically, translated by Gusnita.

\begin{tabular}{|c|c|c|c|}
\hline & Types & $\begin{array}{r}\mathrm{N} \\
\text { umber }\end{array}$ & entage $^{\text {Perc }}$ \\
\hline & $\begin{array}{l}\text { Insertio } \\
n\end{array}$ & $58^{1}$ & $5 \%$ \\
\hline $\mathrm{L}$ & $\begin{array}{l}\text { Alterna } \\
\text { tion }\end{array}$ & $1^{8}$ & $5 \%$ \\
\hline $\mathrm{L}$ & $\begin{array}{c}\text { Congru } \\
\text { ent } \\
\text { Lexicalization }\end{array}$ & $8^{1}$ & $0 \%^{7,}$ \\
\hline
\end{tabular}

3.1.1 Insertion

Jurnal JILP (Jurnal Ilmiah Langue and Parole) Vol. 4 No. 2 (2021) ISSN : 2581-0804 
Occurs when lexical items from one language are incorporated into another language. The lexical items of language are words (noun, adjective, preposition). After of collecting all the data, the researcher found $158(61,5 \%)$ data of insertion.

\subsubsection{Alternation}

Occurs between meaning that alternation is used when speaker mix languages with a phrase. After collecting all the data the researcher found $81(31,5 \%)$ data of alternation.

\subsubsection{Congruent}

Lexicalization

Refers to the situation where two languages share grammatical structures, which can be filled lexically with elements from either language. After collecting all the data the researcher found $18(7,0 \%)$ data of congruent lexicalization.

\section{Mixing}

\subsection{The Reasons of Using Code-}

There are several reasons according to Hoffman, namely talking about particular topic, being empathy about something, repetition, expressing group identity

\begin{tabular}{|c|r|r|r|}
\hline & Reasons & $\begin{array}{r}\mathrm{N} \\
\text { umber }\end{array}$ & $\begin{array}{r}\text { Perc } \\
\text { entage }\end{array}$ \\
\hline 1 & $\begin{array}{c}\text { Talking } \\
\text { about } \\
\text { particular topic }\end{array}$ & 3 & 1, \\
\hline 2 & $\begin{array}{c}\text { Being } \\
\text { empathy about } \\
\text { something }\end{array}$ & 4 & $17 \%$ \\
\hline 3 & $\begin{array}{c}\text { Repetiti } \\
\text { on }\end{array}$ & 2 & $67 \%$ \\
\hline 4 & $\begin{array}{c}\text { Expressi } \\
\text { ng group } \\
\text { identity }\end{array}$ & - & - \\
\hline
\end{tabular}
topic

\subsubsection{Talking about particular}

The first reasons of using code-mixing is talking about particular topic. Sometimes, a speaker feels free and more comfortable to express their emotional feelings in a language that is not their everyday language. From the data collected, the researcher found three data (1, $17 \%)$.

something

3.2.2 Being empathy about

Empathy statement is also used when someone who is talking using a language that is not native tongue suddenly wants to be empathy about something, he/she either intentionally, will mix from his second language to their second language. on the other hand, there are some cases where people feel more convenient to be empathy in their second language rather than in their first language. From the data collected, the researcher found four data $(1,55 \%)$.

\subsubsection{Repetition}

A bilingual wants to clarify their speech so that it will be understood more by listener, they can sometimes use both of the languages that he master saying the some utterance. The researcher found twelve utterances $(4,67 \%)$.

\subsection{The factors of code-mixing}

According to Eunhee Kim(2006: 47) there are some factors influencing the use of codemixing.

\begin{tabular}{|c|c|c|}
\hline $\begin{array}{c}\text { Fact } \\
\text { ors }\end{array}$ & $\begin{array}{c}\text { Num } \\
\text { ber }\end{array}$ & $\begin{array}{c}\text { Percent } \\
\text { age }\end{array}$ \\
\hline $\begin{array}{c}\text { Mess } \\
\text { age } \\
\text { intrinsic } \\
\text { factor }\end{array}$ & 2 & $0,77 \%$ \\
\hline $\begin{array}{c}\text { Habi } \\
\text { tual factor }\end{array}$ & - & - \\
\hline
\end{tabular}

3.3.1 Message intrinsic factor

As mentioned in the previous, direct quotation or reported speech triggers language mixing among bilingualism cross-linguistic. The researcher found 2 of data message intrinsic factor especially direct quotation $(0,77 \%)$

\subsubsection{Habitual factor}

Habitual is also one of that influencing people used code-mixing. Someone who always does the some thing and it also does all the time or continously so it will be habitual. Habitual factor tells about invited guests Deddy Corbuzier it self. 


\section{CONCLUSION}

After collecting all the data, the researcher found 257 utterances that contain code-mixing. By using the Pieter Muysken's theory, the researcher found that there were three types of code-mixing. There were 158 data of insertion $(61,5 \%), 81$ data of alternation $(31,5 \%), 24$ data of congruent lexicalization $(7,0 \%)$.

To answer the second problem, the researcher used Hoffmann's theory about the reason of using code-mixing. The researcher found that there are only three reason of using code-mixing were talking about particular topic there were 3 data $(1,17 \%)$, being empathy about something there were 4 data $(1,55 \%)$, repetition used clarificarion there were 12 data $(4,67 \%)$.
To answer the third problem, the researcher used Eunhee Kim's theory about factors of code-mixing. The researcher found that message intrinsic factor 2 data $(0,77 \%)$, and the last habitual factor, this tells about invited guests Deddy Corbuzier itself.

The researcher hopes that this thesis can be additional material for researcher to write a thesis on the title of code-mixing. This Thesis, the researcher hopes that readers can more understand about code-mixing, and can also increase vocabulary by watching Deddy Corbuzier's YouTube channel, because the podcast always uses two languages, namely Indonesian and English. 


\section{Bibliography}

[1]Bathia and Ritchie. 2004. "The Handbook of Bilingualism". Malden: Blackwell Publishing Ltd. Accessed on January 17, 2021, at $3.07 \mathrm{pm}$.

[2]Creswell, Jhon W. 2013. "Research Design: Qualitative, Quantitative, and Mixed Method Approaches". United States: America. Accessed on January 18, 2021, at $2.05 \mathrm{pm}$.

[3]Djajasudarma, Fatimah. 2006." Metoda Linguistik Ancangan Metoda Penelitian dan Kajian". Bandung: Refika Aditama. Accessed on January 17, 2021, at 8.00 am.

[4]Helianthusonfri, Jefferly. 2020. "Stop Jadi Youtuber Kalo Nggak Tau Cara Marketingnya". Jakarta: Gramedia. Accessed on January 5, 2021, at $10.00 \mathrm{am}$.

[5]Hoffmann, Charlotte. 2014. : "An Introduction To Bilingualism" Newyork: Routledge. Accessed on January 18, 2021, at 10.12 am.

[6]Kim, Eunhee. 2006. "Reasons and Motivation for Code Mixing and Code Switching". Tesol. Accessed on January 18, 2021, at $6.20 \mathrm{pm}$.

[7]Leedy, Paul D, and, Jeanne Ellis Ormrod. 2015. "Practical Research Planning and Design". Malaysia: Vivar. Accessed on January 19, 2021, at $11.15 \mathrm{pm}$.

[8]Liu, Ping. 2006. "Code Switching and Code Mixing" Germany. Accessed on January 5, 2021, at $7.00 \mathrm{pm}$.

[9]Marzona, Yessy. 2017. "The Use Of Code Mixing Between Indonesian And English In Indonesian Advertisement Of Gadis." Jurnal Ilmiah Langue and Parole 1(1):238-
48. Accessed on December 30, 2021, at $11.30 \mathrm{pm}$.

[10]Muysken, Pieter. 2000. " Bilingual Speech: a typology of code mixing". Cambridge: Cambridge University Press. Accessed on January 16, 2021, at $5.00 \mathrm{pm}$.

[11]Pratama, Putu Agus Eka. 2020. "Sosial Media dan Sosial Network" Informatika Bandung. Accessed on December 29, 2021, at $6.00 \mathrm{pm}$.

[12]Salam, Rusidah, Ratnawati and Faradiba Amalia. 2016. "An Analysis of Code Mixing Used By Maestro Gate 107 , 5 Fm Radio An- 38 Nouncers in Muslim University of Indonesia." TAMADDUN Jurnal Bahasa, Sastra Dan Budaya 15(1):23-30. Accessed on December 30, 2021 , at $411 \mathrm{pm}$.

[13]Sugiyono. 2013. " Metode Penelitian Kuantitaif, Kualitatif, dan R\&D". Bandung: Alfabeta. Accessed on January 19,2021 , at $3.34 \mathrm{pm}$

[14]Wardhaugh, Ronald. 2010. "An Introduction To Sociolinguistics" United Kingdom: Wiley-Blackwell Sixht Edition. Accessed on January 18, 2021, at $11.00 \mathrm{am}$.

[15]Wardhaugh, Ronald, and Janet M. Fuller 2015. "An Introduction To Sociolinguistics" United Kingdom: WileyBlackwell Seventh Edition. Accessed on January 19, 2021, at $5.45 \mathrm{pm}$.

[16]Windyawati, Yulianti Octavia Aurima. 2018. "An Analysis of Indonesia English Code Mixing in Facebook Status Users." PROJECT Professional Journal of English Education 1(5):539. Accessed on December 29, 2021, at $2.00 \mathrm{pm}$ 